\title{
ФОРМУВАННЯ ЗДОРОВОГО СПОСОБУ ЖИТТЯ В ПІДЛІТКОВОМУ ВІЦІ - ЗАПОРУКА ЗБЕРЕЖЕННЯ ЗДОРОВОГО ПОТЕНЦІАЛУ НАЦІЇ
}

\author{
I. О. Богданець, Н. В. Петренко \\ ДвНЗ «Тернопільський державний медичний університет \\ імені І. Я. Горбачевського МОЗ Украӥни»
}

У статті наведено результати анкетування студентів щодо способу їх життя та виявлення можливих чинників, які погіршують стан їх здоров’я.

\section{HEALTHY LIFESTYLE FORMATION IN ADOLESCENTS - THE GUARANTEE OF KEEPING OF HEALTH POTENTIAL OF THE NATION}

\author{
I. O. Bohdanets, N. V. Petrenko
}

\section{Horbachevsky Ternopil State Medical University}

The article presents the results of questionnaire survey of students according their lifestyle and the identification of possible factors, impairing their health.

Вступ. В останні роки в Україні значно погіршується стан здоров'я дітей і молоді [6]. Саме стан здоров'я цієї категорії населення належить до важливих медико-соціальних проблем, оскільки від нього залежить майбутнє держави, її трудовий та інтелектуальний потенціал [2]. Результати численних досліджень свідчать, що в Україні за останні 10 років захворюваність серед дітей зросла на 20 \%, поширеність хронічних захворювань - у 2,87 раза, на 22,9 \% збільшився контингент дітей-інвалідів [4].

Охорона власного здоров'я - це безпосередній обов'язок кожного [7]. Сучасні блага цивілізації такі, як неправильний спосіб життя, шкідливі звички, гіподинамія, переїдання дуже часто є причиною ряду захворювань, починаючи з молодого віку [9]. Саме тому виховання здорового покоління $є$ пріоритетом державної політики в галузі охорони здоров'я [1].

Разом із біологічними факторами, медичною допомогою та навколишнім середовищем, спосіб життя людини є одним із чотирьох основних показників, які визначають рівень здоров'я. Спосіб життя належить до основних детермінант здоров'я, ступінь впливу якого на стан здоров'я значно перевищує дію багатьох інших чинників [8].

Дотримання здорового способу життя повинно формуватися з дитячих років, підлітковий період (c) І. О. Богданець, Н. В. Петренко, 2018 період пошуку себе і реалізації як дорослої, зрілої особистості, є найкращим часом для закріплення сформованих поведінкових реакцій, які мають на меті збереження власного здоров'я [3, 5].

Саме тому метою роботи було вивчення способу життя молодих людей - студентів та виявлення можливих чинників, які погіршують стан їх здоров'я.

Проведено опитування студентів Рокитнівського медичного училища щодо способу їх життя. В анкетуванні взяло участь 54 студенти віком 15-20 років. Анкета включала 16 запитань щодо загальних параметрів способу життя, кратності прийому їжі, характеру харчування, питтєвого режиму та складу, фізичної активності, тривалості та якості сну.

Усі опитані респонденти були жіночої статі. Середній вік опитаних становив $(16,4 \pm 1,2)$ року. Слід звернути увагу, що опитування охопило студентів, які належать до двох вікових періодів: підлітковий (13-16 р.) - 14 (25,9 \%) та юнацький (17-21 р.) $40(74,1 \%)$.

Як показало дослідження, 15 (27,8 \%) студентів $\epsilon$ жителями міста, а 39 (72,2 \%) - приїжджими, серед яких 19 (35,2 \%) винаймають житло, 20 (37,0 \%) проживають в гуртожитку. Отримані дані свідчать про те, що більшість (39 (72,2 \%)) молодих людей повинні самі піклуватись про приготування їжі, виділяючи на це час. 
Результати анкетування засвідчили, що 28 (51,9 \%) студентів харчуються 3 рази на день, 2 - 25 (46,3 \%), один раз - 1 (1,8 \%). Аналіз розподілу їжі протягом дня показав, що 21 (38,9\%) студентів розпочинають свій день без сніданку, 5 (9,3 \%) - без обіду.

Розподіл об'єму їжі між прийомами теж був різним. Так, 5 (9,3 \%) студентів найбільший об'єм їжі споживає на сніданок, 22 (40,7 \%) - на обід, а 27 (50,0 \%) - на вечерю. Таким чином, більшість молодих людей 49 (90,7 \%), споживає їжу в другій половині дня. Опитування причин такого розподілу харчового раціону показало, що молоді люди віддають перевагу ранішньому сну ніж приготуванню їжі, а сам процес готування переносять на післяобідній час, коли повертаються до помешкання після навчання. Недотримання правильного режиму харчування, 3 переважанням вечірнього прийомуїжі, призводить до захворювань органів травлення, порушення обміну речовин та роботи мозку, порушення режиму сну, що негативно впливає на ефективність навчання та в кінцевому результаті спричиняє погіршення успішності.

Аналіз якісного складу харчового раціону показав, що першу страву один раз на день споживають $40 \%$ студентів. Слід зазначити, що студенти вікової групи до 18 років отримують гарячі обіди один раз на день у їдальні училища. Проте, незважаючи на те, що більшість студентів (65 \%) повинні бути забезпечені гарячим обідом один раз на день, впродовж дослідження було з'ясовано, що лише половина 27 (50,0 \%) харчуються теплими стравами щодня, 19 (35,2%) студентів - один раз на 2-3 дні, а 16 (29,6 \%) мають повноцінний обід інколи (1-2 рази на тиждень).

Таким чином, проведене дослідження свідчить про те, що більшість студентів Рокитнівського медичного училища харчуються погано, оскільки не дотримуються режиму харчування, переїдають в другій половині дня та нехтують гарячим обідом та першими стравами.

Рідина - невід'ємний компонент та основа для нормальної роботи всього організму. Ії̈ нестача може викликати низку проблем зі здоров'ям. Через брак води в організмі порушуються обмінні процеси, що не дозволяє токсинам виводитися та відбувається зневоднення. Людське тіло звикає до нестачі води, що не найкращим чином позначається на функціонуванні організму. Проте велике значення має не тільки кількість випитої рідини, але і її якість. Найчастіше проблеми зі здоров'ям виникають тому, що багато хто дійсно забуває пити просту воду. Люди п'ють каву, чай, соки, смузі, газовані напої, компоти, квас, вино, пиво - все, що завгодно, але тільки не воду.

Проведене опитування щодо питтєвого раціону показало, що найбільш вживаним напоєм є чай, його, як основне джерело рідини, споживає трохи більше половини 30 (55,6 \%) студентства, на другому місці $\epsilon$ звичайна проста вода, її прихильниками є 19 (35,2 \%) опитаних, ще 15 (27,8 \%) віддають перевагу каві, а 12 (22,2 \%) тамують спрагу солодкими газованими напоями (Coca-cola, Sprite тощо). Аналізуючи об'єм спожитої рідини встановлено, що рідину в об'ємі менше 500 мл на добу вживає 2 (3,7 \%) студентів, 500-1000 мл - 25 (46,3\%), 1000-1500 мл - 17 (31,5\%), 1500-2000 мл - 9 (16,7\%), більше 2000 мл - 1 (1,9\%).

Проведене дослідження свідчить про недостатнє вживання рідини молодими людьми, оскільки тільки менше половини з них (48,2%) вживають їі в кількості 1000-2000 мл на добу, більшість опитаних не вживає достатньої кількості рідини, крім того неправильним $€$ якісний склад рідини, оскільки для її тамування тільки третина (31,5 \%) студентства використовує звичайну воду, в той час, як більшість молодих людей зловживає кавою та солодкими газованими напоями.

Тіло людини на 75 \% складається із води, яка необхідна для підтримання всіх процесів життєдіяльності, а найменше відносне його обезводнення призводить до стресового стану клітин, у тому числі й головного мозку. Тому підтримка водного балансу необхідна для студентів. Неправильний питтєвий режим та недостатній об'єм рідини не відповідає потребам молодого організму, який інтенсивно росте, розвивається та працює (навчається), й призводить до швидкої втомлюваності, зниження працездатності, млявості, головного болю, зниження уваги, гальмування процесів пам'яті, хронічної втоми та сонливості, що в кінцевому результаті спричиняє виснаження компенсаторних можливостей та розвиток захворювань.

Не менше значення для підтримання стану здоров'я на належному рівні має рухова активність та заняття спортом. Сучасний світ, за рахунок оптимізації людської діяльності, технічного, навчального і трудового прогресу, значно менше рухається, ніж скажімо 10-20 років тому. Така гіподинамія негативно впливає на діяльність життєвозабезпечувальних систем, спричиняє розвиток хвороб цивілізації, пришвидшує старіння і смерть. Ще в давнину Гіппократ запевняв, що «Гімнастика, фізичні вправи, ходьба повинні обов'язково увійти у повсякденний побут кожного, хто хоче зберегти працездатність, здоров'я, повноцінне 
радісне життя». Гіподинамія негативно впливає на молодий організм, у період гормональної перебудови організм підлітка не завжди адекватно реагує на посилені розумові навантаження в період навчального процесу, тоді як адекватна фізична активність могла 6 значно знизити інтелектуальну напруженість.

Як показали дослідження, серед студентської молоді 33 (61,1 \%) осіб займаються фізичними вправами інколи за бажанням, 12 (22,2 \%) - тільки на парах фізкультури, 3 (5,6 \%) - відвідують фітнес-клуби, 2 (3,7 \%) щоранку роблять ранкову зарядку і тільки 4 (7,4 \%) взагалі не займаються спортом.

Аналізуючи отримані дані можна стверджувати, що рухова активність студентів училища теж потребує інтенсифікації та залучення молодих людей до занять спортом. Фізична активність відповідно до вікових потреб значно підвищує стійкість організму до дії цілого ряду різних несприятливих факторів, сприяє зміцненню здоров'я людини та підвищенню працездатності, стимулює захисні сили організму на підвищення потенціалу здоров'я. Крім того, регулярні заняття спортом покращують будову тіла, що $\epsilon$ важливим фактором у сучасному світі.

Важливим чинником, який впливає на формування здорового організму, є тривалість сну, проте не менш важливим є санітарно-гігієнічний стан приміщення, де людина спить, а особливо інтенсивність освітлення.

Дослідження показали, що студенти Рокитнівського медичного училища сплять в середньому $(6,7 \pm 0,6)$ год на добу, причому 5-6 год сплять 5 (9,3 \%) студентів, 7-8 год - 29 (53,7 \%), 9-10 год - 7 (13,0 \%), а $13(24,1 \%)$ дали відповідь «як виходить». Незважаючи на відносно адекватну тривалість сну, в більшості студентів занепокоєння викликає стан місця, де вони проводять ніч.

Результати опитування засвідчили, що 34 (62,9 \%) студентів закривають на ніч штори, створюючи темряву, тоді як у 20 (37,1 \%) - наявне додаткове освітлення від природних (місяць, зірки) і штучних (вуличні ліхтарі) нічних джерел. Проте, незважаючи на щільно закриті шторами вікна, у 46 (85,2 \%) студентів вночі в кімнаті наявне освітлення від діодних джерел - телефонів, ноутбуків, телевізорів тощо або увімкнена нічна лампа. На загал лише 8 (14,8 \%) респондентів відпочивають вночі в повній темряві.

Під час сну організм людини виробляє 70 \% добової кількості мелатоніну, гормону, який відіграє величезну роль в підтримці здоров'я, профілактиці захворювань і продовженні молодості, який регулює біоритми: допомагає пристосуватися до зміни дня і ночі, зниження рівня холестерину в крові, знижує руйнівну дію гормонів стресу, які можуть ушкодити серцевий м'яз тощо. Адекватна секреція мелатоніну можлива лише вночі та в повній темряві. Тому, зменшення тривалості сну або наявність освітлення порушують його продукцію. Зниження рівня мелатоніну є підґрунтям до виникнення хронічної втоми, виснаження, ожиріння, частих депресій, стресів, цукрового діабету, зниження розумових функцій, а у жінок - розвитку безпліддя.

На якість сну також впливає санітарно-гігієнічний стан приміщення. Проведене опитування показало, що вологе прибирання один раз на тиждень проводять 26 (48,1 \%) студентів, 3 рази на тиждень - 9 (16,7\%), тоді як решта 19 (35,2 \%) не сильно переймаються чистотою в приміщенні, де мешкають, прибираючи його при потребі. 28 (51,9 \%) щоденно провітрюють кімнату перед сном, 24 (44,4\%) - роблять це інколи, а 2 (3,7 \%) не провітрюють ніколи.

Таким чином, незважаючи на відносно задовільну тривалість сну 7-8 год у більшості студентів 29 (53,7\%), занепокоєння викликають санітарно-гігієнічні характеристики студентських кімнат, які вночі залишаються занадто освітленими, не зовсім чистими та не провітреними.

Висновки. 1. Більшість студентів Рокитнівського медичного училища харчуються погано, оскільки не дотримуються режиму харчування, переїдають в другій половині дня та нехтують гарячим обідом та першими стравами.

2. Молоді люди вживають недостатню кількість рідини на добу та зловживають кавою та солодкими газованими напоями.

3. Рухова активність студентів училища теж потребує інтенсифікації та залучення молодих людей до занять спортом.

4. Незважаючи на відносно задовільну тривалість сну 7-8 год у більшості студентів, занепокоєння викликають санітарно-гігієнічні характеристики студентських кімнат, які вночі залишаються занадто освітленими, не зовсім чистими та не провітреними.

5. Підлітковий період $\epsilon$ найкращим часом для набуття звичок із дотримання правил здорового способу життя. 


\section{СПИСОК ЛІТЕРАТУРИ}

1. Цьось Анатолій Фізичне виховання, спорт і культура здоров'я у сучасному суспільстві / Анатолій Цьось, Юзеф Бергєр, Олександр Сабіров // Збірник наукових праць. 2015. - № 3 (31). - С. 202-210.

2. Годун Н. І. Раціональне харчування сучасних підлітків як здоров'язберігаючий фактор / Н. І. Годун // Молодий вчений. - 2016. - № 9.1 (36.1). - С. 46-49.

3. Зелененко Н. О. Використання засобів фізичної культури в регулюванні працездатності студентів / Н. О. Зелененко // Релігія, релігійність, філософія та гуманітаристика у сучасному інформаційному просторі: національний та інтернаціональний аспекти : зб. наук. пр. - Монреаль : CPM «ASF», 2016. - С. 178-180.

4. Дослідження особливостей харчування студентів вищої школи як складової способу життя / Н. М. Козік, Н. А. Стратійчук, Г. М. Пилип, Л. Г. Логуш // Молодий вчений. - 2017. - № 3.1 (43.1). - С.18-23.

5. Шестопалов В. М. Дослідження рівноважного стану води та проблема впливу питної та мінеральної води на здоров'я людини / В. М. Шестопалов, Н. Б. Овчиннікова // Геол. журн. - 2017. - № 1 (358). - С. 23-36.

6. Ковтюк Н. І. Зміни стереотипів харчування у сучасних школярів / Н. І. Ковтюк // Актуальные проблемы транспортной медицины. - 2014. - № 1 (35). - С. 33-36.

7. Лобода В. С. Шляхи формування мотивації студентів до здорового способу життя (на прикладі майбутніх фахівців фармацевтичної галузі) / В. С. Лобода // Х Міжнародна наук.-практ. конф., м. Київ, 19-21 лист. 2015 р. - К., 2015. - С. 125-136.

8. Мальченко Світлана Дослідження світлового забруднення нічного неба / Світлана Мальченко, Микола Слюсаренко // Теоретична фізика і астрономія. - 2014. № 15. - C. 81-86.

9. Artificially lit surface of Earth at night increasing in radiance and extent / C. M. Christopher, Theres Kuester, Alejandro Sánchez de Miguel [et al.] // Science Advances. 2017. 